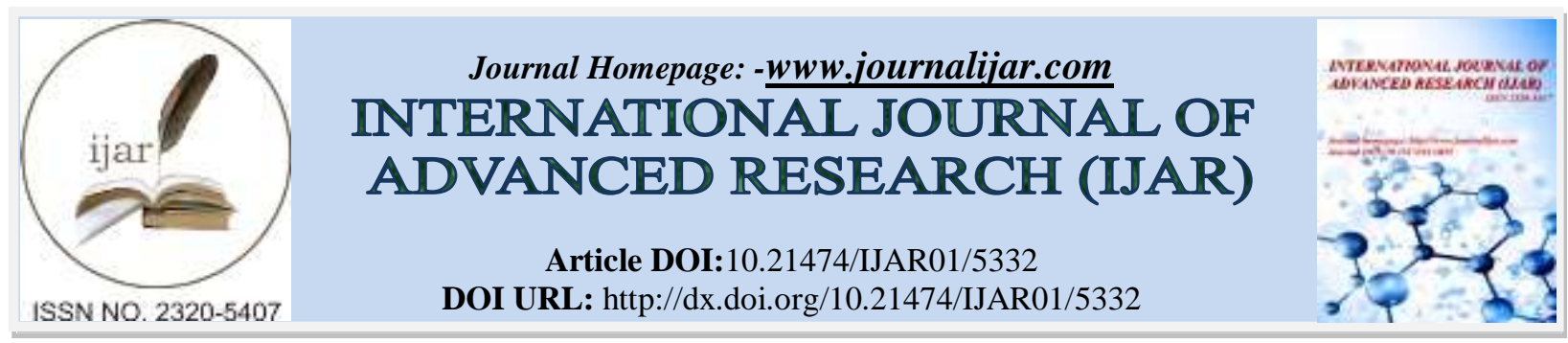

RESEARCH ARTICLE

\title{
DEVELOPMENT OF K-300 CONCRETE MIX FOR EARTHQUAKE-RESISTANT HOUSING INFRASTRUCTURE IN INDONESIA.
}

Fahrizal Zulkarnain.

Department of Civil Engineering, Faculty of Engineering, University of Muhammadiyah Sumatera Utara.

\section{Manuscript Info}

Manuscript History

Received: 05 July 2017

Final Accepted: 07 August 2017

Published: September 2017

Key words:-

composition of concrete mix, concrete strength, concrete strength test, earthquake-resistant housing.

\section{Abstract}

In determining the strength of K-300 concrete mix that is suitable for earthquake-resistant housing infrastructure, it is necessary to research the materials to be used for proper quality and quantity so that the mixture can be directly applied to the resident's housing, in the quake zone. In the first stage, the examination/sieve analysis of the fine aggregate or sand, and the sieve analysis of the coarse aggregate or gravel will be carried out on the provided sample weighing approximately 40 kilograms. Furthermore, the specific gravity and absorbance of aggregates, the examination of the sludge content of aggregates passing the sieve no. 200, and finally, examination of the weight of the aggregate content. In the second stage, the planned concrete mix by means of the Mix Design K-300 is suitable for use in Indonesia, with implementation steps: Planning of the cement water factor (CWF), Planning of concrete free water $\left(\right.$ Liters $\left./ \mathrm{m}^{3}\right)$, Planning of cement quantity, Planning of minimum cement content, Planning of adjusted cement water factor, Planning of estimated aggregate composition, Planning of estimated weight of concrete content, Calculation of composition of concrete mixture, Calculation of mixed correction for various water content. Implementation of the above tests also estimates the correction of moisture content and the need for materials of mixture in kilograms for the K-300 mixture, so that the slump inspection result will be achieved in planned $8-12 \mathrm{~cm}$. In the final stage, a compressive strength test of the K-300 experimental mixture is carried out, and subsequently the composition of the K-300 concrete mixture suitable for one sack of cement of $50 \mathrm{~kg}$ is obtained for the foundation of the proper dwelling. The composition is consists of use of Cement, Sand, Gravel, and Water. At the end of the study, the paper will be published in the International Journal of Advanced Research (IJAR) (TS) and the International Journal of Advanced Research (IJAR) (TS + 1). The draft paper has already been submitted in the National Science Meeting (TS), and this has already been done in the National Science Meeting (TS + 1). Prepare a draft development of the K-300 concrete mixed model in the first year of research (TS) and produce a new K-300 concrete mix product for earthquake-resistant housing infrastructure at $(\mathrm{TS}+1)$.

Copy Right, IJAR, 2017,. All rights reserved.
Corresponding Author:- Fahrizal Zulkarnain.

Address:- Department of Civil Engineering, Faculty of Engineering, University of Muhammadiyah Sumatera Utara. 


\section{Background:-}

Some researchers have tested in particular to increase the compressive strength of concrete versus normal concrete, as did Zulkarnain et al. (2016), by addition of paper and also foam to increase the compressive strength of concrete.

Concrete can be used in several applications such as pavement, building, foundation, pipeline installation, dam, and other civil building infrastructure (Piyamaikongdech, 2007; Zulkarnain and Ramli, 2011). One alternative to the mixture of concrete components is to use lightweight concrete while maintaining the compressive strength of the existing concrete, so this becomes the solution for the existing concrete mixture. Huang's research (2009) indicates that lightweight concrete can be used as structures in residential buildings by the addition of stiff fibers to concrete mixtures. This is to add strength especially on columns and also beams on building structures to withstand loads.

The innovation of concrete technology has also been applied in countries such as Malaysia in 2005 with Smart Tunnel project in Kuala Lumpur, using Lightweight Concrete Method (LCM). With this project the floods that inundate Kuala Lumpur and its surrounding areas can be overcome and channeled into the tunnel to further be directed to the sea (Lee and Hung, 2005).

Research conducted by Kuehn (2010) in Canada shows that particles of $10 \mu \mathrm{m}$ in size can be used for concrete mixtures in building structures. It can be argued that the results of the study are close to the results obtained with ash for concrete mixtures, so the basis of that research is well suited for use in disaster areas. Furthermore, a study by Zulkarnain (2011) suggests that concrete mixtures can be increased in strength by adding silica powder, especially for lightweight concrete that can be used for houses in disaster areas with relatively fast processing and does not require a high cost for each building produced. Previous research by Karolina et al. (2014) concluded that the volcanic ash from Mt. Sinabung could be one of the aggregates in the concrete mix.

A study by Zulkarnain (2015) on the strength of concrete with the addition of volcanic ash indicates that this addition can increase the strength of the concrete in such a way that it is possible to reconstruct the earthquakedamaged housing around Mount Sinabung.

The innovation of the research in 2016-2018 produced a new K-300 concrete mix for earthquake-resistant housing infrastructure in Indonesia, which can be directly applied to the earthquake area. For the area of North Sumatra, for example, this is appropriate for housing around the safe area of Mount Sinabung, both for short-term and long-term.

\section{Literature Review:-}

Preliminary study by Zulkarnain et al. (2014) said that a mixture of palm oil can also be used for lightweight concrete mixtures. In this research, the increase of compressive strength value of concrete is obtained which can also be used for housing in disaster area. The results have been published in the Journal of Civil Engineering Research 2014.

In Proceedings of the 3rd International Conference on the Geohazard Information Zonation and 5th Seminar \& Short Course of HASTAG (GIZ 2014-HASTAG 5), p. 90-98, Karolina et al. (2014) presented the results of research on ash of eruption of Mount Sinabung with the following conclusions: (1) It is found that the water cement factor is so high that it affects the compressive strength of the concrete produced. (2) The visual observation results show that the surface of the brick has the same shape as the particle equation, thus the surface of the brick becomes flat. (3) The use of brick material from the ash of Mount Sinabung resulted in the increase of absorption which in the study by $4.142 \%$. (4) Based on the resulting compressive strength, the addition of $10 \%$ ash will result in a compressive strength of $211.01 \mathrm{~kg} / \mathrm{cm}^{2}$ with treatment and presence of $\mathrm{SiO}_{2}$ dominance in concrete mixture. (5) From the research, it is found that Mount Sinabung ash can be used in the mix for brick making.

The use of ash of eruption of mount Sinabung in concrete mix will increase the compressive strength of concrete at 28 days of testing. The results of the compressive strength test at 28 days were $166.90 \mathrm{~kg} / \mathrm{cm}^{2}$ using no mixture (0\%), the compressive strength at 28 days was $173.72 \mathrm{~kg} / \mathrm{cm}^{2}$ by $5 \%$ mixture, the compressive strength at 28 days was $207.14 \mathrm{~kg} / \mathrm{cm}^{2}$ by $10 \%$ mixture, and the compressive strength at 28 days was $130.97 \mathrm{~kg} / \mathrm{cm}^{2}$ by $15 \%$ mixture. Other chemical compositions are: $\mathrm{SiO}_{2}=74.3 \%, \mathrm{AL}_{2} \mathrm{O}=3.3 \%, \mathrm{CAO}=1.79 \%$ (Karolina et al., 2014). 
Zulkarnain F. (2015), through internal research in Muhammadiyah University of North Sumatra (UMSU), has examined the strength and resilience characteristics of concrete mixtures using silica powder for housing development. Thus, the preliminary study for this research is very supportive and can be the basis for research of $\mathrm{K}$ 300 concrete mix for earthquake-resistant housing infrastructure in Indonesia.

Inspection of materials becomes the decisive factor in increasing the compressive strength of the tested sample. Selection of materials and techniques or ways of mixing is also a matter of priority before samples are tested. Samples will be tested with cube and cylinder molds for each planned age of up to 28 days. From the test results will be obtained a good value and used as a reference for the mixture of concrete in the disaster area.

In the last section, the composition of the concrete mix for every 1 sack of $40-\mathrm{kg}$ cement can be determined based on the volume of the mixture for 1 sack of 40-kg cement. Comparison of volume of mixture for 1 sack cement of $40 \mathrm{~kg}$ and final composition of cement: sand: gravel: water can be achieved for earthquake-resistant housing infrastructure in Indonesia.

\section{Method Of Implementation:-}

Primary data is data obtained from the results of research conducted in the laboratory which, among others, are:

a) The materials prepared in the study for mixing of concrete, among others, are: sand, aggregate and Bond Crete supplements. Examination of the materials in the preparation of the study are: Sieve analysis or filtration of coarse aggregate, sieve analysis or filtration of fine aggregate or sand, specific gravity and aggregate absorbance, mud content of aggregate or passing sieve no. 200, and the weight of the aggregate content.

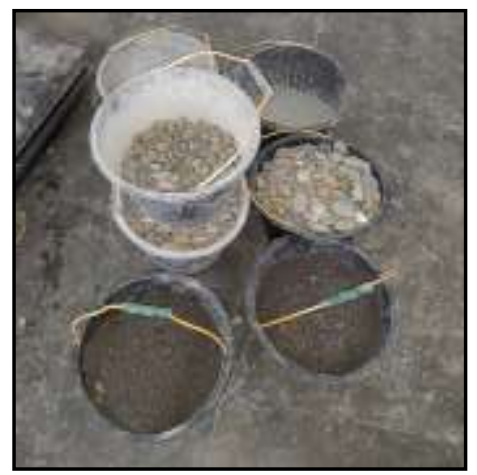

Figure 1:- Materials for testing

b) Planning of Concrete Mix design using the DoE Method that has been adapted to the conditions of Indonesia.

c) Several types of alternatives are used for the preparation and making of cylindrical test objects which include:

- Planning used for development or construction of residential houses. The material used is Andalas cement, weighing $\pm 40 \mathrm{~kg}$ per sack.

- The schedule of activities undertaken in this study include: Characteristic examination, Planning of the composition of the mixture, Preparation of experimental mixture at the initial stage of this study (3 cubes of $15 \mathrm{~cm} \times 15 \mathrm{~cm}$, and 3 cylinders of $15 \mathrm{~cm}$ in diameter and height of $15 \mathrm{~cm}$ ), Quality Inspection of Experimental Concrete Mix with 7 days of age.

In general the resume of design of concrete mix is as follows:

1. Data on Ingredients:

- $40 \mathrm{~kg}$ Bosowa Cement.

- Additive Bond Crete.

- Water at Public Laboratory of Medan.

- Aggregates as follows:

\begin{tabular}{|l|l|l|}
\hline Aggregate examination & Fine aggregate & Coarse aggregate \\
\hline - Type & Natural sand & Natural gravel \\
\hline - Gradation & Zone 2 BS & - \\
\hline - Maximum diameter & - & $40 \mathrm{~mm}$ \\
\hline
\end{tabular}




\begin{tabular}{|l|l|l|}
\hline - Specific gravity of SSD & 2.58 & 2.61 \\
\hline - Absorbance & $2.17 \%$ & $0.93 \%$ \\
\hline - Mud content & $1.69 \%$ & $0.52 \%$ \\
\hline - Weight of content & $1426.86 \mathrm{Kg} / \mathrm{m}^{3}$ & $1472.47 \mathrm{Kg} / \mathrm{m}^{3}$ \\
\hline
\end{tabular}

2. Data for Planning:

1) Quality of K-300 concrete.

2) Planned slump of 6-9 cm.

3) Planned standard deviation of $50 \mathrm{~kg} / \mathrm{cm}^{2}$.

4) The planning method of DoE has been adapted to the conditions of Indonesia.

3. Results of Planning:

Composition of mixture per $1 \mathrm{~m}^{3}$ of concrete (Aggregate in state of SSD).
1) Cement
$=448.72 \mathrm{~kg}$.
2) Fine aggregate (sand)
3) Coarse aggregate (gravel)
$=614.70 \mathrm{~kg}$.
4) Water
$=1141.58 \mathrm{~kg}$.
$=175.00$ Littre.

4. Making of Experimental Mixture

\begin{tabular}{|l|l|}
\hline Day /Date & Monday/August 7, 2017 \\
\hline Site & $\begin{array}{l}\text { Civil Engineering Laboratory of Public Polytechnic of } \\
\text { Medan }\end{array}$ \\
\hline Type of Mixture & K-300 \\
\hline Object Test & $\begin{array}{l}3 \text { cubes of } 15 \times 15 \mathrm{~cm} \text { and } 3 \text { cylindersof } \phi=15 \mathrm{~cm}, \text { height } \\
\text { of } 15 \mathrm{~cm}\end{array}$ \\
\hline Additive & Bond Crete \\
\hline Water content of fine aggregate (sand) & $5.82 \%$ \\
\hline Absorbance of fine aggregate (sand) & $2.17 \%$ \\
\hline Water content of coarse aggregate (gravel) & $0.72 \%$ \\
\hline Absorbance of coarse aggregate (gravel) & $0.93 \%$ \\
\hline Slump obtained & $8.17 \mathrm{~cm}$ \\
\hline
\end{tabular}

5. The results of examination of the compressive strength of experimental concrete at age 7 days (estimated 28 days)

\begin{tabular}{|l|l|r|}
\hline & & 7 days \\
\hline Average compressive strength & $\mathrm{Kg} / \mathrm{cm}^{2}$ & 369.48 \\
\hline Standard deviation & $\mathrm{Kg} / \mathrm{cm}^{2}$ & 5.99 \\
\hline Characteristic compressive strength & $\mathrm{Kg} / \mathrm{cm}^{2}$ & 459.67 \\
\hline
\end{tabular}

6. Recommendations:

1) Based on examination of experimental mixtures, the resulting mixture composition according to the planning can meet the required quality.

2) In the implementation is required to conduct supervision of the quality of the materials of mixture and the quality of concrete by way of sampling according to the provisions and conduct testing of samples in the laboratory.

3) For the purpose of correction of moisture content of the mixture, the examination of the moisture content of the aggregate shall be carried out prior to mixing.

4) The composition of the mixture in units of weight (aggregate in state of SSD).

5) The composition of the mixture in volume unit (aggregate in state of SSD). 


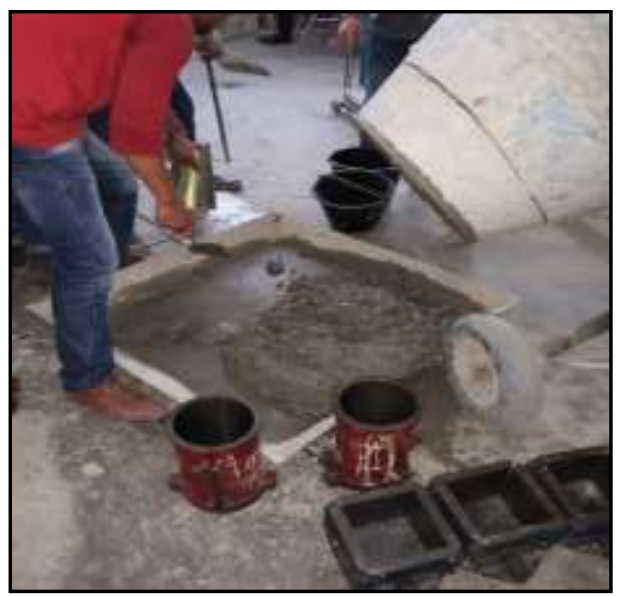

Figure 2:- Mixing of ingredients

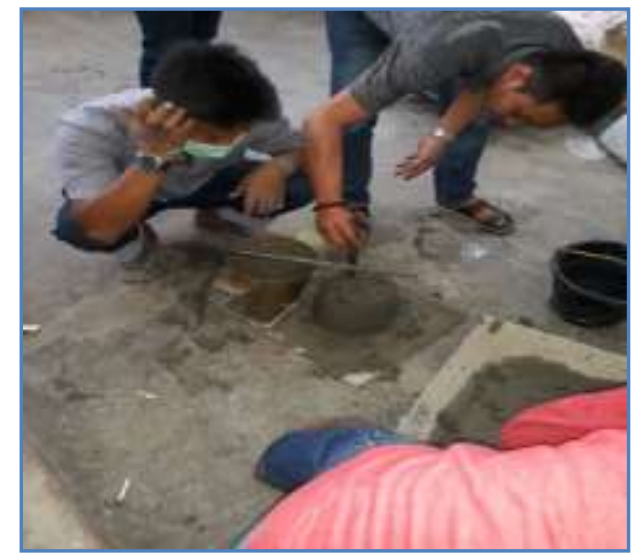

Figure 3:- Slump test process

The compacting process lasts only about 5 seconds; this process is useful to remove various air and cavities that are around the concrete mixture. All concrete mixtures that have good slump value will be inserted into the mold and vibrated. The vibration is applicable to all cube and cylinder molds in this study.

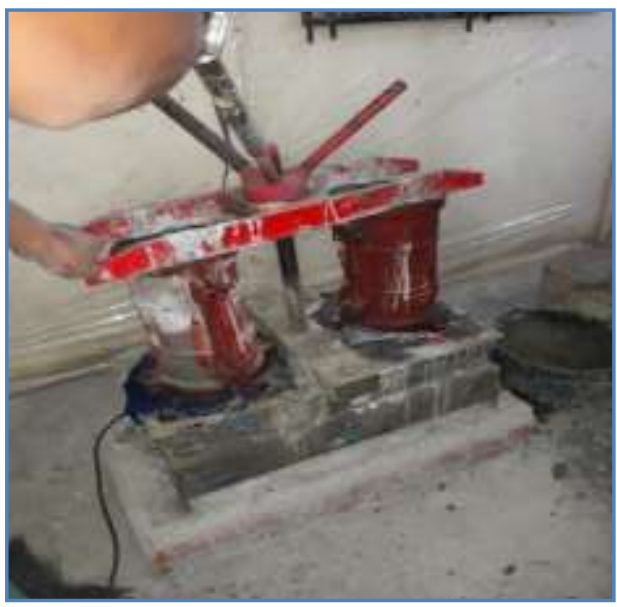

Figure 4:- The compaction process uses a vibrating engine on all samples. 


\section{Results Of Testing:-}

Design of K-300 Concrete Mix:-

The data and materials used during the research process are as follows:
a. Quality of concrete
: K-300.
b. Planned slump
$:(6-9) \mathrm{cm}$
c. Materials:
- Fine aggregate
: Type
Specific gravity of SSD
$=$ natural sand.
Absorbance
$=2.58$.
Gradation
$=2.17 \%$.
$=$ zone $2 \mathrm{BS}$.
- Coarse aggregate : Type
$=$ natural gravel.

\section{Planning Steps:-}

\section{Planning of Cement Water Factor (CWF)}

Estimation of compressive strength of concrete $\left(\mathrm{kg} / \mathrm{cm}^{2}\right)$ with CWF of 0.5 corresponds to type of cement and aggregate using Table 1.

Table 1:-Planning of Cement Water Factor (CWF)

\begin{tabular}{|l|l|l|l|l|l|}
\hline \multirow{2}{*}{ Type of Cement } & \multirow{2}{*}{ Type of Aggregate } & \multicolumn{4}{|c|}{ Compressive Strength $\left(\mathbf{k g} / \mathbf{c m}^{2}\right.$ ) } \\
\cline { 3 - 6 } & 3 days & 7 days & 28 days & 91 days \\
\hline $\begin{array}{l}\text { Ordinary Portland Cement } \\
\text { (Type I) }\end{array}$ & $\begin{array}{l}\text { Natural } \\
\text { (Not destroyed) }\end{array}$ & 200 & 280 & 400 & 460 \\
\cline { 2 - 6 } & Crushed stone & 230 & 320 & 450 & 530 \\
\hline
\end{tabular}

Based on the graph of the relationship between Compressive Strength with Cement Water Factor, the CWF value of 0.52 is obtained. Maximum value of CWF for this planning is limited to 0.39 so that the CWF value used is 0.39 .

2. Planning of Concrete Free Water $\left(\mathrm{Liter} / \mathrm{m}^{3}\right)$ :-

Estimates of the amount of free water $\left(\mathrm{kg} / \mathrm{m}^{3}\right)$ required for different levels of work can be determined using Table 2 .

Table 2:-Planning of Concrete Free Water $\left(\mathrm{Liter} / \mathrm{m}^{3}\right)$

\begin{tabular}{|c|l|l|l|l|l|}
\hline \multicolumn{2}{|c|}{ Aggregate } & \multicolumn{4}{c|}{ Planned Value of Slump (mm) } \\
\hline Diameter max. (mm) & Type & $0-10$ & $10-30$ & $30-60$ & $60-180$ \\
\hline \multirow{2}{*}{20} & Natural & 135 & 160 & 180 & 190 \\
\cline { 2 - 6 } & Crushed stone & 170 & 190 & 210 & 225 \\
\hline \multirow{2}{*}{40} & Natural & 115 & 140 & 160 & 175 \\
\cline { 2 - 6 } & Crushed stone & 155 & 175 & 190 & 205 \\
\hline
\end{tabular}

The rough aggregate used is a natural type with a maximum diameter of $40 \mathrm{~mm}$ and a natural fine aggregate. With planned value of slump of 6-9 cm, it is planned to use free water as much as 175.00 liters $/ \mathrm{m}^{3}$ of concrete.

\section{Planning of the Amount of Cement:-}

Based on the smallest CFW value and Free Water then the planned use of cement is as much as:

Total Cement $=\frac{\text { Free } \text { Water } \text { Content }}{C F W}=\frac{175.00}{0.39}=448.72 \mathrm{~kg} / \mathrm{m}^{3}$

\section{Maximum Cement Level:-}

The minimum cement quantity for this planning is set at $400 \mathrm{~kg} / \mathrm{m}^{3}$. Thus, the amount of cement used is the calculated amount of cement which is equal to $448.72 \mathrm{~kg} / \mathrm{m}^{3}$.

\section{Adjusted Cement Water Factor}

Since the amount of cement used does not change, the value of CWF does not need to be adjusted so that the CWF value remains at 0.39 . 


\section{Estimated Aggregate Composition:-}

From the graph of the relationship between the maximum size of coarse aggregate $(30 \mathrm{~mm})$, the gradation of fine aggregate (Zone $2 \mathrm{BS})$, planned value of slump $(10 \pm 2 \mathrm{~cm})$ and $\mathrm{CWF}=0.42$ then the composition is obtained:

Fine aggregate : Coarse aggregate $=35 \%: 65 \%$.

\section{Estimated Weight of Concrete Content:-}

From the graph of the relation between the relatively specific gravity of the dry aggregate of the surface and the amount of free water, it is estimated that the weight of the wet concrete content is $2380 \mathrm{~kg} / \mathrm{m}^{3}$.

\section{Calculation of the Composition of the Concrete Mixture:-}

From the above planning steps for the mixture, the composition per mixed $\mathrm{m}^{3}$ (aggregate in a state of SSD) is obtained as follows:
- Cement
: $448.72 \mathrm{~kg}$.
- Fine Aggregate (Sand)
$: 614.70 \mathrm{~kg}$
- Coarse Aggregate (Split)
$: 1141.58 \mathrm{~kg}$.
- Water
: 175.00 liter.

\section{Calculation of Correction of the Mixture for Various Water Content:-}

The composition of the mixture per $\mathrm{m}^{3}$ of concrete in step 8 above is based on the assumption that the aggregate used is in the state of SSD (saturated surface dry). For aggregates not in the state of SSD, the correction of the mixture is carried out as follows:
- Cement
: Fixed.
- Fine Aggregate (Sand)
: Sand of SSD + (Water Content of sand - Degree of Saturation of sand) $\times$ Sand of SSD .
- Coarse Aggregate (Split)
: Gravel of SSD + (Water Content of gravel - Degree of Saturation of gravel) $\times$ Gravel of SSD .
- Water
: Water of SSD - Sand Correction - Gravel Correction.

With the description of the research road map above, the results we will achieve in the research will be as expected. This has been done by previous researchers, with the same methods and workings, but the number of molds is increased overall, so a better result is obtained to determine the strength of columns and beams on the main housing/settlement structures. And this can be used in the reconstruction of housing in the vicinity of Mount Sinabung, North Sumatra.

The subsequent process after consideration is to test the compressive strength of each specimen, so that the strength of the sample is known. Testing of compressive strength is also performed on the cylinder by using a cover on the top, so that the flat portion is obtained for more accurate data resulting from the test.

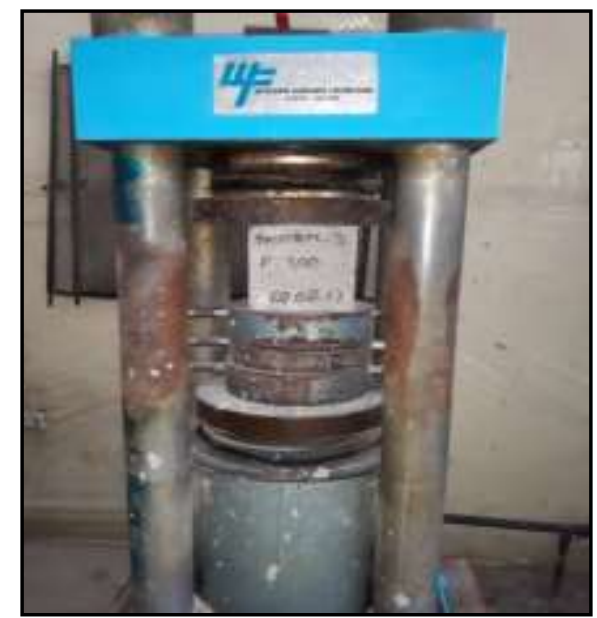

Figure 5:- Testing of Compressive Strength 


\section{Conclusions:-}

Some results are obtained from testing for both cube and cylinder sample forms according to the age of the plan, including:

1. Based on examination of experimental mixtures, the composition of the mixture as a result of planning can meet the requested quality.

2. In the implementation is required to perform quality control of materials of mixture and quality of concrete by way of sampling according to the provisions and conduct testing of samples in the laboratory.

3. For the purpose of correction of moisture content of the mixture, the examination of the moisture content of the aggregate shall be carried out prior to mixing.

4. The K-300 mix with additive of $1 \%$ Bond Crete can be used for earthquake-resistant housing infrastructure in Indonesia.

5. The use of such mixtures for all infrastructures in buildings or housing is in accordance with established provisions.

\section{Acknowledgments:-}

The research was conducted with the assistance of the Ministry of Research and Technology, Higher Education of the Year 2016/2017 through the Applied Product Research scheme (PPT).

\section{References:-}

1. Huang, Y.J. (2009). Fiber-Reinforced Syntactic Foam. A Dissertation Presented to the Faculty of the Graduate School, University of Southern California. In Partial Fulfilment of the Requirements for the Degree Doctor of Philosophy (Materials Science).

2. Karolina R, Syahrizal, Putra M.A, Prasetyo T.A. (2014). The Use of Vulcanic Ash of Mount Sinabung Eruption as the Substitution of Fine Agregate in Making Batako (Mass-Produced Brick). Proceedings of the $3^{\text {rd }}$ International Conference on the Geohazard Information Zonation and $5^{\text {th }}$ Seminar \& Short Course of HASTAG (GIZ 2014-HASTAG 5), p. 90-98.

3. Kuehn, S.C, \& Froese, D.G. (2010). Tephra from Ice - A Simple Method to Routinely Mount, Polish, and Quantitatively Analyze Sparse Fine Particles. Microsc. Microanal. 16, p. 218-225.

4. Lee, Y.L, \& Hung, Y.T. (2005). Exploitation of Solid Wastes in Foamed Concrete: Challenges Ahead. Dhir RK, Newlands MD, McCarthy A, Editors. Use of Foamed Concrete in Construction. London, Thomas Telford. p. 15-22.

5. Piyamaikongdech, A. (2007). Ductile Lightweight Concrete for Lightweight Structural Application. M. S. Thesis, The University of Texas at Arlington.

6. Zulkarnain, F. (2011). Strength and Durability Properties of Lightweight Foamed Concrete for Housing Construction, PhD Thesis, Universiti Sains Malaysia.

7. Zulkarnain, F, dan Ramli, M. (2011). Performance of Foamed Concrete Mix Design with Silica Fume for General Housing Construction,European Journal of Technology and Advanced Engineering Research, Issue 2.

8. Zulkarnain, F, Sulieman M.Z, Serri E. (2014). The Effect of Mix Design on Mechanical and Thermal Properties Oil Palm Shell (OPS) Lightweight Concrete, Journal of Civil Engineering Research, Vol.4, No. 3-A, 2014.

9. Zulkarnain, F. (2015). Karakteristik Kekuatan dan Ketahanan Campuran Beton dengan Penambahan Serbuk Silika untuk Pengembangan Perumahan, APB Universitas Muhammadiyah Sumatera Utara, Mei 2015.

10. Zulkarnain, F, Sulieman M.Z, Fadila R. (2016). The Potential Usgae Paper Fiber Reinforced Foam Concrete (PFRCFC) Wall Paneling System As An Idea Building Material. International Journal Of Advanced Research (IJAR), Vol. 4, Issue 2, 2016. 